\title{
APORTES CRÍTICOS PARA UM LETRAMENTO LITERÁRIO NA EDUCAÇÃO BÁSICA
}

\section{CRITICAL CONTRIBUTIONS TO A LITERARY LITERACY IN BASIC EDUCATION}

\author{
Priscilla Lopes Béda Rodrigues ${ }^{1}$ \\ Renato de Oliveira Dering ${ }^{2}$
}

Recebido em: 06 dez. 2018

Aceito em: 24 mar. 2019

DOI 10.26512/aguaviva.v4i2.23715

RESUMO: Sabe-se que a leitura e a literatura são componentes curriculares de extrema importância na constituição dos sujeitos, auxiliando na criticidade e ampliação da bagagem cultural. O presente artigo, de cunho qualitativo, busca promover uma crítica acerca do ensino de Literatura, tomando como base os aportes do Letramento. Assim, será realizada uma análise no modelo de ensino de literatura na educação básica e os apontamentos da BNCC (BRASIL, 2017) sobre leitura. Tem-se, ainda, como objetivo, uma discussão sobre a formação de leitores literários, pensando que estes são formados. Pretende-se, assim, refletir sobre as funções da literatura, a transformação do sujeito e sua formação enquanto um possível leitor literário. Para tanto, fazem parte dos pressupostos teóricos os estudos de literatura e literatura infantil de Proença Filho (2012), Abramovich (1983) e Frantz (2011); bem como os estudos de Letramento Literário de Cosson (2012). Ao fim, será realizada uma proposta de letramento com obras de dois autores goianos: Christie Queiroz e Cora Coralina.

Palavras-chave: Ensino de Literatura; Formação de Leitores; Práticas de Letramento.

\begin{abstract}
It is known that reading and literature are curricular components of extreme importance in the constitution of the subjects, aiding in the criticality and expansion of cultural baggage. This qualitative article seeks to promote a critique about Literature teaching, based on the contributions of Literacy. Thus, an analysis will be carried out on the teaching model of literature in basic education and BNCC's (BRAZIL, 2017) notes on reading. We also have as

\footnotetext{
${ }^{1}$ Aluna do curso de Especialização em Estudos Literários e Ensino de Literatura pela Universidade Federal de Goiás (UFG). Graduada em Pedagogia no Centro Universitário de Goiás - Uni-ANHANGUERA. E-mail:

${ }^{2}$ Doutorando em Letras e Linguística pela Universidade Federal de Goiás (UFG). Professor Assistente no Centro Universitário de Goiás - Uni-ANHANGUERA. Líder-pesquisador do grupo CNPq/FORPROLL/UFVJM. E-mail: renatodering@gmail.com
} priscilla.lb@hotmail.com
\end{abstract}


objective a discussion about the formation of literary readers, thinking that these undergo formation. It is intended, therefore, to reflect on the functions of literature, the transformation of the subject and its formation as a possible literary reader. For that, the studies of literature and children's literature of Proença Filho (2012), Abramovich (1983) and Frantz (2011) are part of the theoretical assumptions; as well as Cosson's Literacy in Literature studies (2012). At the end, a proposal of literacy will be made with works by two authors from Goiás: Christie Queiroz and Cora Coralina.

Keywords: Literature Teaching; Training of Readers; Practices of Literacy.

\section{INTRODUÇÃO}

Falar em competência leitora, ainda no século XXI, parece ser um mito que repercute com as mesmas indagações de outros tempos. Os alunos estão saindo da escola sem estarem aptos a serem cidadãos de opinião - críticos e reflexivos -, que atuariam com responsabilidades na sociedade e nela iriam intervir. Infelizmente, a premissa de que dificilmente essas pessoas terão um futuro promissor, parece ainda se perpetuar.

É visível que, em determinados contextos, haja profissionais da educação que não se propõem a buscar diferentes tipos de leituras para seus alunos; alguns, sequer, leem para os estudantes. O que temos, portanto, é que muitos professores não conseguem criar um momento prazeroso de leitura com os seus alunos, muito pelo contrário, o que mais se vê em escolas são estudantes que recebem como punição um livro para ler ou ficar na biblioteca pelo simples ato de estar lá.

A partir dessa problemática, buscaremos refletir sobre possíveis estratégias que contribuam para que os alunos, em ambiente escolar, possam ter, não apenas acesso, mas a prática de leitura literária, tomando como foco a literatura infantil e sua importância para seu desenvolvimento social, tornando-os sujeitos de opinião, isto é, críticos e reflexivos enquanto futuros cidadãos.

Quem teve uma infância em meio a livros sabe da extrema importância que é a literatura infantil. Ela poder ser uma resposta visto quantas são as dificuldades enfrentadas pelas crianças no ato de ler e de escrever. Segundo Abramovich (1983), é de suma importância para a formação de qualquer criança ouvir muitas histórias; escutá-las é o início da aprendizagem para ser um leitor. Entendemos, assim, que ser leitor é ter um caminho absolutamente infinito de 
descoberta e de compreensão do mundo, potencializando esse sujeito para seu pleno desenvolvimento em diversos aspectos escolares e sociais.

Sabe-se que a linguagem é uma forma de comunicação social aprendida desde o início de vida, logo, parte preponderante do contexto real na vida das crianças. Com isso, a presente pesquisa mostrará a importância que a literatura tem na formação do sujeito, bem como refletirá acerca desta formação no que se refere ao desenvolvimento dos sujeitos.

Entende-se que os sujeitos se desenvolvem não apenas por si mesmos, mas também na relação com os outros e o meio. Assim, quando introduzidos no meio cultural, a possibilidade de desenvolvimento aumenta, visto que no convívio com outros sujeitos, aprenderão novos saberes, bem como ensinarão, em uma relação de troca (VYGOTSKY, 1991).

Abordando o desenvolvimento da criança, é importante entender que para Vygotsky (1991), o elemento histórico da criança dissolve-se com o cultural. Compreende-se, portanto, que a criança que vê seus pais ou responsáveis com o hábito de leitura, provavelmente se tornará uma criança leitora, mas apenas ver não será totalmente garantido, claro que a criança conviver com leitores é importante, mas ela deve ser estimulada diariamente, deve sentir todos os sentimentos de ler/escutar um livro e ficar encantada ou desapontada; então, ela poderá se tornar uma leitora literária. Assim, essa criança será uma criadora cultural, ou seja, não será apenas mais uma leitora, mas também terá a capacidade de criar através da sua reflexão.

O que mais se vê hoje em dia, no entanto, são pessoas com pouco senso crítico, presas a opiniões dos outros, sem saber tirar suas próprias conclusões. Isso ocorre devido a uma cultura brasileira que pouco valoriza a leitura, principalmente a leitura literária. Logo, compreendemos que a leitura é de suma importância na formação dos sujeitos, para que eles saiam do estado de inércia, ou seja, que não sabem colocar suas opiniões de forma plausível e fundamentada. $\mathrm{O}$ hábito da leitura transforma pessoas para que tenham consciência de tudo que se passa ao seu redor, ela aumenta a capacidade de interação com a sociedade. Frantz (2011, p. 28) pontua que: "Nesse caso a palavra deixa de ser um instrumento de dominação para se transformar em instrumento de libertação do homem, possibilitando, a partir da reflexão, que ele se torne sujeito de sua história".

Deste modo, tem-se como problemática inicial o questionamento acerca da importância da leitura literária na formação dos sujeitos e sua efetiva potencialização no processo de desenvolvimento da criança. O foco, portanto, está em refletir sobre as funções da literatura para a formação de sujeitos mais críticos e reflexivos, vislumbrando promover não apenas a 
criatividade como sua constituição enquanto cidadão. Para tanto, é importante compreender as funções da literatura, enquanto produto cultural-artístico, e sua importância na formação dos sujeitos, bem como discutir sobre as estratégias de leitura na promoção de um letramento literário. Após tais discussões, pode-se, então, analisar como a literatura é fator preponderante para a formação e desenvolvimento dos sujeitos.

\section{Material e Métodos}

A referente pesquisa foi realiza por meio de revisão bibliográfica e um estudo teóricocrítico sobre os pressupostos de letramento literário. Assim, uma análise de uma obra literária infantil, do autor goiano Christie Queiroz, foi realizada, bem como da também autora goiana Cora Coralina. As obras são: No mundo de Cabeça Oca e Contas de dividir e trinta e seis bolos. Tomamos como base que "toda investigação nasce de algum problema teórico/prático sentido. Este dirá o que é relevante ou irrelevante observar, os dados que devem ser selecionados. Esta seleção exige uma hipótese, conjectura e/ou suposição, que servirá de guia ao pesquisador". (MARCONI; LAKATOS, 2003, p. 97). E, falando de leitura e letramento, é imprescindível essa conjectura proposta.

\section{Panorama Literário e Pressupostos no Ensino de Literatura}

A literatura, sem dúvida, é um componente curricular importante para a formação dos sujeitos em processo de escolarização. Por isso, para se discutir sobre o tema, é importante entender como surgiu a literatura, e o início da literatura no Brasil. No século XI, com a chegada dos portugueses, criaram-se também os primeiros textos escritos no Brasil. Na época, esses textos não estavam ligados à literatura tal qual a conhecemos hoje, pois os objetivos das grandes navegações eram outros, a exploração de riquezas.

Surgiram, assim, desse modo de escrita, os primeiros textos que foram integrados a nossa história como literatura informativa, que tem como exemplo a carta de Pero Vaz de Caminha; e literatura de catequese, para o processo de catequização. Ambas fazem parte da escola literária, intitulada por teóricos da área, como Quinhentismo, compreendida no período de 1500 e 1601. Segue um trecho da carta que Caminha registrou:

No dia seguinte, depois de comer, fomos em terra cortar lenha e lavar roupa. 
Uns duzentos e sessenta nativos já se sentem tão seguros entre nós que nem arcos trazem mais.

$[\ldots]$

Enquanto isso, dois carpinteiros faziam a Grande Cruz com bastões já cortados ontem especialmente para isso. Os mais curiosos se aproximaram dos carpinteiros, mas não creio que fosse por causa da cruz, que para eles não tem significado algum.

Outra coisa os fascinava.

Observaram eles uma ferramenta de ferro que facilitava muito o trabalho dos carpinteiros.

Os nativos não conheciam o ferro! E aí começou um tal de: AIPOTA KITI (eu desejo cortar), AIPOTA KISSÊ (desejo faca), MBOIREHEPA RENHEMU (por quanto você vende?) (TERMI, 2000. p. 48-49).

Em meados do século XII, surge, então, o movimento estético denominado de Barroco, que é fortemente marcado pelo resgate de valores medievais. Nesse período da literatura se percebe uma forma conflituosa, o sujeito não sabe se quer viver a vida, por ser muito curta ou se deseja salvar a sua alma. Como características, temos uma linguagem mais difícil de ser compreendida. Para Proença Filho (2012):

[...] o Renascimento buscou nos valores da antiguidade greco-romana a base para uma concepção de vida que veio de encontro à tradição medieval. Se, num primeiro instante, os novos ideais prevaleceram, a reação não demorou, e a tentativa de conciliação entre razão e fé gerou a crise revelada nos textos representativos do Barroco (PROENÇA FILHO, 2012, p. 143).

Depois no século XVIII, surge o Arcadismo, remetendo à valorização da natureza, das cenas campestres, do bucolismo, o pastoralismo, entre outros. No Brasil, o Arcadismo está ligado ao ciclo do ouro, quando se inicia, também em terras tupiniquins, o processo de urbanização. Sobre esse período, Proença Filho (2012, p. 176) diz: "de tudo o que dissemos sobre o século XVIII europeu, a conclusão é que nele não encontramos um estilo homogêneo e único, mas, como já ficou assinalado, um cruzar-se de correntes espirituais e estéticas".

No início do século XIX, surge o Romantismo, marcado pelo liberalismo. Com isso, manifesta-se na educação o incentivo na alfabetização, a criação de escolas, contribuindo para surgimento de um novo público leitor e consumidor de arte.

O público dá sentido e realidade à obra, e sem ele o autor não se realiza, pois ele é de certo modo o espelho que reflete a sua imagem enquanto criador. Os artistas incompreendidos, ou desconhecidos em seu tempo, passam realmente 
a viver quando a posteridade define afinal o seu valor. Deste modo, o público é fator de ligação entre o autor e a sua própria obra. A obra, por sua vez, vincula o autor ao público, pois o interesse deste é inicialmente por ela, só se estendendo à personalidade que a produziu depois do estabelecido aquele contacto indispensável. Assim, à série autor-público-obra, junta-se outra: autor-obra-público. Mas o autor, do seu lado, é intermediário entre a obra, que o criou, e o público, a que se dirige; é o agente que desencadeia o processo, definindo uma terceira série interativa: obra-autor-público. (CANDIDO, 2000, p. 33-34)

Enfim, podemos dizer que o Romantismo é o liberalismo na arte da burguesia em ascensão. No Brasil, a primeira geração do Romantismo contribui para o sentimento nacionalista, na época que houve a independência do Brasil. Obras como Canção do exílio de Gonçalves Dias, que é o autor fundamental dessa época, expressam o nacionalismo, que traz temas como a pátria, a natureza e o índio.

Os ritos semibárbaros dos Piagas,

Cultores de Tupã, a terra virgem

Donde como dum trono, enfim se abriram

Da cruz de Cristo os piedosos braços;

As festas, e batalhas mal sangradas

Do povo Americano, agora extinto,

Hei de cantar na lira.- Evoco a sombra

Do selvagem guerreiro!... Torvo o aspecto,

Severo e quase mudo, a lentos passos,

Caminha incerto, - o bipartido arco

Nas mãos sustenta, e dos despidos ombros

Pende-lhe a rôta aljava... as entornadas,

Agora inúteis setas, vão mostrando

A marcha triste e os passos mal seguros

De quem, na terra de seus pais, embalde

Procura asilo, e foge o humano trato (DIAS, 1959, p. 473).

A segunda geração romântica, conhecida como "mal do século", é marcada por um sentimento de tristeza, tédio, angustia, que chega à vontade de morrer. Autores brasileiros de destaque deste momento são José de Alencar, Joaquim Manuel de Macedo, Casimiro de Abreu, entre outros, são autores do individualismo e subjetivismo, dúvida, desilusão, cinismo e negativismo boêmio.

Já a terceira geração é voltada para questões sociais. Épocas ligadas às lutas pelo abolicionismo e à guerra do Paraguai. Obras que fazem parte dessa época são Machado de Assis, Castro Alves, Luís Delfino, entre outros. Castro Alves ganha destaque nessa geração: 
Era um sonho dantesco... o tombadilho

Que das luzernas avermelha o brilho.

Em sangue a se banhar.

Tinir de ferros... estalar de açoite...

Legiões de homens negros como a noite,

Horrendos a dançar...

Negras mulheres, suspendendo às tetas

Magras crianças, cujas bocas pretas

Rega o sangue das mães:

Outras moças, mas nuas e espantadas,

No turbilhão de espectros arrastadas,

Em ânsia e mágoa vãs! (ALVES, 1977, s/p)

Na segunda metade do século XIX, ocorre uma mudança no Romantismo, a época em que acontece uma grande evolução nas ciências e a consequência que será a $2^{\mathrm{a}}$ Revolução Industrial. Nesse período, surge o Realismo, conhecido por alguns como os antirromânticos. A arte literária, então, se volta para entender uma realidade social e psicológica afetada pelas transformações citadas. As vertentes desse movimento se desdobram em tanto em tentar explicar a natureza humana, bem como questões mais racionais. Segundo Proença Filho (2012, p. 210) "os escritos realistas pretendem mostrar essa nova visão do mundo. Os escritores assumem uma atitude semelhante à dos homens da ciência".

Os movimentos que permeiam os séculos XIX e XX, de um modo geral, retomam questões gerais já apontadas em outras épocas, tendo como um ponto diferencial o Prémodernismo, que traz um caráter regionalista e documental. O Modernismo, então, aparece como, primeiramente, um período de destruição, de quebra de padrões, que trazem uma discussão daquilo que está sendo divulgado. A segunda fase desse movimento preza pela construção e maturidade, fala do amor, da solidão, a temática social, entre outros. Chega também, junto a essa etapa, a fase do romance de 30, quando a marca principal é o regionalismo e temas sociais. A terceira fase do Modernismo é marcada pelo otimismo, marcado pela redemocratização, momento em que se volta para a estética sem se esquecer da temática social.

Toda a agitação espiritual que marcou a Europa nos começos do século XX vai repercutir em nosso país com características próprias. A crise social europeia não nos atingia diretamente. A guerra não manchava de sangue nossos campos, nem feria de morte nossas urbes. A guerra era uma questão de solidariedade humana e de angústia dos mais lúcidos, que percebiam a importância da relação que une os acontecimentos do mundo. Antes, assiste- 
se, no Brasil, a um misto de estagnação e inconformismo, aliás, a situação já se vinha delineando desde algum tempo (PROENÇA FILHO, 2012, p. 300).

Esse panorama acerca dos movimentos literários, nos remete a compreender como a literatura, enquanto texto escrito, insere-se no país, bem como ela é postulada nos currículos da Educação Básica. Temos, assim, que a literatura, no início, era apenas escritos, leis, formas científicas, etc.; depois passa a ser composta de escritas voltadas a problemas sociais, questões culturais ou até mesmo para entretenimento, sem nenhuma obrigação.

\section{Função da Literatura como Componente Curricular Pedagógico e Social}

Quando se fala em literatura, não é resumida apenas à palavra, mas também falamos em história, filosofia, arte, gramática, geografia, ciências, enfim, tudo. E na escola a literatura é voltada a periodização, os alunos estudam obras literárias daquela determinada época, mas o que acontece é que na escola frisa-se apenas a obra literária para o aluno decorar, mas é mais que isso, é a nossa história. "Na escola, não aprendemos acerca do que falam as obras, mas sim do que falam os críticos. [...] [Portanto,] ao ensinar uma disciplina, a ênfase deve recair sobre a disciplina em si ou sobre seu objeto [e o que ele permeia]?” (TODOROV, 2009, p.27, grifo do autor, apud DERING, 2012, p. 21). Tem-se, então, que “[...] fica evidente que se mudam as maneiras de conceber a literatura, pois se antes os livros eram lidos, hoje se leem autores e suas origens, e deste ponto se critica e teoriza a literatura dita contemporânea." (DERING, 2012, p. 22).

Observado isso, corrobora Eco ao refletir sobre as funções da literatura. Eco (2013) diz que os objetos literários são imateriais apenas pela metade, isto é, apesar de ter uma estrutura física, papel, plataformas digitais ou apenas uma história contada, ela nos dá muito mais do que isso. Os livros nos levam a mundos inimagináveis pelos quais podemos pensar e refletir acerca de nossas atitudes, bem como as atitudes dos outros e da sociedade.

Eco (2013) ainda levanta outra questão importante: "Para que serve este bem imaterial?’. Compreende-se, então, que a literatura traz informações, tanto para a saúde, quanto para o vocabulário e também para a alma. É através da literatura que temos uma boa compreensão para a nossa língua, entre tantas funções como de criar identidade e também comunidades. Logo, uma importante função da literatura é formar uma sociedade. É através da cultura e da história que não cometemos os mesmos erros do passado. Portanto, a literatura nos permite ir além, visto que: 
As obras literárias nos convidam à liberdade da interpretação, pois propõem um discurso com muitos planos de leitura e nos colocam diante das ambiguidades e da linguagem e da vida. Mas para poder seguir neste jogo, no qual cada geração lê as obras literárias de modo diverso, é preciso ser movido por um profundo respeito para com aquela que eu, alhures, chamei de intenção do texto (ECO, 2013, p. 12).

Isso acontece com muita frequência, pois acham que os livros devem ser interpretados apenas de um jeito. É claro que a literatura apresenta evidências que nos fazem chegar a certas conclusões, mas podemos sim ter várias hipóteses para um determinado acontecimento. Há também uma grande contribuição na formação da nossa língua individual, na linguagem que Eco (2013) chama de neotelegráfica, onde palavras e, até mesmo, frases inteiras são abreviadas. No século XXI, quando o Brasil finalmente está cercado de tecnologia, as crianças já têm meios para ter acesso a livros sem sair de casa, seja por meio de celulares, tablet ou computadores, geralmente conectados à Internet.

É importante lembrar que a literatura tem uma grande importância social, pois a falta do conhecimento de mundo que encontramos nos livros está fora do alcance dos marginalizados, àqueles que não tiveram a oportunidade de se ter conhecimento de valores, onde a educação e a discussão não foram apresentadas.

Chegando à verdadeira função da literatura em que, segundo Eco (2013), não é apenas a transmissão de ideias morais boas ou más, é a aquisição do conhecimento, que nos dá a capacidade de apreciar o belo, o bonito, traz-nos emoção, faz-nos vivenciar momentos de tensão, alívio, medo, frustrações carregadas pelos personagens, e que posteriormente serão purificadas. E, finalmente, a literatura traz-nos a consciência da transformação da sociedade.

Como discutido anteriormente, a literatura tem um papel importante, pois nos mostra a história de nossa sociedade e sujeitos. "Lembramos, pois, que diferentes épocas e culturas têm formas distintas de constatar tempo e espaço e, deste modo, podendo não apenas convergir pensamentos, como, também, contrapor outras épocas e ideologias.” (DERING, 2012, p. 2). Essa é uma das principais funções da literatura. Contribui Frantz (2011, p. 30), ao pontuar que "a escola tem, portanto, um compromisso maior que é propiciar ao sujeito o desenvolvimento da sua capacidade de leitura do mundo". Com isso, é de suma necessidade compreender a importância da literatura, que além de contribuir para o desenvolvimento da linguagem, vai definir a identidade do sujeito, desenvolvendo também consciência individual e social. 
Frantz (2011, p. 33) também aponta que "acreditamos que é muito importante para o aluno a convivência com os mais variados tipos de texto, pois cada um revelará ao leitor uma faceta diferente da relação do texto-mundo". Então, para falar sobre literatura infantil devemos saber a importância que tem para a formação da criança e sempre dar preferência às leituras prazerosas, ao invés de apresentar algo meramente instrutivo. Através do livro a criança perceberá o que acontece, ou seja, verá a realidade. Com isso, a criança terá capacidade de refletir, sentir e interagir na sociedade.

Podemos verificar que sempre, quando o substantivo "literatura" é subordinado pelo adjetivo "infantil", tem-se cometido, ao longo dos tempos, sérios equívocos. O maior deles é a sua preocupação pedagógica, que acaba por reduzi-lo à condição de mero subsidiário da educação formal, relegandoo à simples condição de livro paradidático. Espera-se, nesse caso, que a criança lendo aprenda a escrever corretamente, a partir da internalização das estruturas da língua, ao mesmo tempo que se aproveita para lhe passar ensinamentos morais de toda ordem (FRANTZ, 2011, p. 44).

A escola deve trabalhar a literatura com o objetivo de que o aluno possa construir seu conhecimento, dando acesso ao acervo científico-cultural da humanidade. A leitura, assim, deve ser mediadora entre o leitor e o mundo; e a literatura tem como principal função mostrar ao leitor uma visão aberta de mundo, em que ele pode encontrar novas possibilidades, colocando novos valores no lugar dos retrógrados ou revitalizando os anteriores. Freire (2015) diz que:

O fato de me perceber no mundo, com o mundo e com os outros me põe numa posição em face do mundo que não é a de quem nada tem a ver com ele. Afinal, minha presença no mundo não é a de quem a ele se adapta, mas a de quem nele se insere. É a posição de quem luta para não ser apenas objeto, mas sujeito também da história (FREIRE, 2015 p. 53).

Portanto, Freire (2015) pontua que não somos apenas objeto da história, mas seu ser. É de suma importância, realizar um trabalho em que o aluno construa sua própria aprendizagem, o aluno não deve utilizar apenas o tempo em que está na escola, esse tempo deve ser utilizado pela escola, capacitando-os a buscar novas formas no decorrer da sua vida, formando então sua autonomia para buscar novos conhecimentos. A literatura, então, como fonte de saber, é algo essencial na vida de qualquer pessoa, para torná-la crítica, um cidadão responsável e conquistar a sua autonomia enquanto sujeito. 


\title{
BNCC e a Formação de Leitores
}

A leitura e seus diversos modos de práticas são um dos pontos chaves da Base Nacional Comum Curricular (BNCC), que aborda ainda sobre a importância de trazer para o contexto de aula obras contemporâneas e de mídias digitais, como no caso de usar uma obra literária e formar um clube do livro, por exemplo, algo que incentive o aluno a continuar a leitura com prazer.

Primeiramente, a BNCC levanta a questão da linguagem como sendo polissêmica, que permite ampliar o significado daquilo que está sendo lido, ativando conhecimentos prévios, sua cultura, sua história. Nesse ponto, quando se fala em formação de leitor e ensino de literatura, é importante levar em conta os vários "significados" que as obras literárias nos proporcionam, dando ênfase no coletivo e no que todos têm a compartilhar. Sobre a temática, pontua a BNCC:

\begin{abstract}
As atividades humanas realizam-se nas práticas sociais, mediadas por diferentes linguagens: verbal (oral ou visual-motora, como Libras, e escrita), corporal, visual, sonora e, contemporaneamente, digital. Por meio dessas práticas, as pessoas interagem consigo mesmas e com os outros, constituindo-se como sujeitos sociais. Nessas interações, estão imbricados conhecimentos, atitudes e valores culturais, morais e éticos. (BRASIL, 2017, p. 61).
\end{abstract}

É importante ao trabalhar a leitura criar oportunidades para que o aluno perceba o gênero do texto que se lê, o contexto no qual ele e o texto estão inseridos, a época, autor, entre tantos elementos necessários para a ampliação do saber. Além de estudar sobre o autor, é importante conhecer as fotos, pinturas, gráficos, sendo possível o aprofundamento também em outros contextos, não ficando algo cansativo para o aluno. Ressalta-se, ainda, a utilização de recursos tecnológicos para garantir aos alunos do século XXI aprendizagem de qualidade.

Sobre tecnologia, a BNCC a aborda como uma forma de expressão, a linguagem em diferentes suportes. Dessa maneira, incentivar os alunos a uma nova forma de interação, aumentando as oportunidades na cultura digital, garantindo novas formas de aprendizagem, é de suma importância, o que facilmente pode ser usado pelo professor. Momentos de debates sobre textos, livros digitais, memes, gifs são algumas das possibilidades que a BNCC pontua como formas de interação dos sujeitos ao mundo tecnológico.

Refletir sobre as transformações ocorridas nos campos de atividades em função do desenvolvimento das tecnologias de comunicação e informação, do uso do hipertexto e da hipermídia e do surgimento da Web 2.0: novos gêneros do discurso e novas práticas de linguagem próprias da cultura digital, 
transmutação ou reelaboração dos gêneros em função das transformações pelas quais passam o texto (de formatação e em função da convergência de mídias e do funcionamento hipertextual), novas formas de interação e de compartilhamento de textos/ conteúdos/informações, reconfiguração do papel de leitor, que passa a ser também produtor, dentre outros, como forma de ampliar as possibilidades de participação na cultura digital e contemplar os novos e os multiletramentos (BRASIL, 2017, p. 70).

Estamos acostumados a trabalhar sempre um ou outro gênero de texto, e a fazer sempre as mesmas perguntas, mas os estudantes, desde o século XX, tem demonstrado mais interesse e discutido o porquê de ler certos livros, expressando rapidamente sua opinião sobre o livro e/ou sobre a imposição das escolhas do professor. É um verdadeiro desafio escolher o "livro certo", mas outro desafio, ainda maior, é despertar o interesse pela leitura, principalmente literária. Diversificar os suportes é um bom começo. Assim, pensar em abordar a:

[...] manifestação da compreensão ativa (réplica ativa) dos textos que circulam nas redes sociais, blogs/microblog, sites e afins e os gêneros que conformam essas práticas de linguagem, como: comentário, carta de leitor, postem rede social33, gif, meme, fanfic, vlogs variados, political remix, charge digital, paródias de diferentes tipos, vídeos-minuto, e-zine, fanzine, fanvídeo, vidding, gameplay, walkthroug, detonado, machinima, trailer honesto, playlists comentadas de diferentes tipos etc. (BRASIL, 2017, p. 71).

Falar sobre essas práticas de leitura é muito novo, ainda que não pareça. Alunos não precisam - e nem devem - ficar mais apenas na escuta, mas terem a oportunidade de participar da leitura e de suas potencialidades, buscando alcançar o entendimento mais amplo. Na leitura, também é essencial, para a compreensão do texto, levar em consideração a vivência de cada um, trazendo também seu conhecimento prévio. Contudo, uma grande barreira para o leitor, logo para o letramento, é a leitura sem significado, isto é, ele lê, mas não entende. É importante, então, trazer expectativas, identificar, no momento de compartilhamento de ideias, expressões ou palavras desconhecidas, pois a criança deve ter a oportunidade de conseguir identificar o tema do referido texto que se lê e ampliar sua bagagem cultural.

\section{Letramento Literário e Formação de Leitores}

Compreendemos o mundo através da linguagem, como vimos, pois será nela que fazemos conexões de saberes, fazendo-nos entender e sermos. Sabemos, também, que como 
expressão da linguagem, a literatura é a porta para a compreensão do mundo, pois ela traz a realidade de maneira não objetiva e sim lúdica e criativa.

Observando isso, temos que: "a linguagem apresenta uma variedade de funções, mas para que possamos compreender cada uma delas, devemos levar em conta os elementos constitutivos de todo o ato de comunicação" (JAKOBSON, 2008, p. 33). A comunicação deve ser entendida, claramente, e o receptor deve entender do assunto que está sendo falado para haver compreensão, ou seja, deve estar por dentro do contexto. Assim, é preciso perceber todos os envoltos na comunicação e as formas de expressão visando a sua função.

Observado isso, temos que Jakobson (2008) cita seis funções da linguagem: (1) a primeira se trata da função referencial, para que a mensagem seja entendida, deve estar no contexto do receptor; (2) a segunda é a função emotiva, em que o próprio remetente deve transferir emoção no momento da mensagem, para que o receptor entenda através da emoção; (3) a terceira é a função conotativa na qual se supõe que uma tomada de decisão do receptor irá depender da mensagem; (4) na quarta função, a mensagem que irá iniciar ou concluir a comunicação, esta é chamada de função fática; (5) a metalinguística, quinta função, é onde se encontra significados das palavras; (6) a função poética, por sua vez, é quando a mensagem toma forma por sua combinação dos eixos linguísticos.

Essa percepção da linguagem pelo professor em seu trabalho com a literatura é de suma importância para um letramento literário e para a formação de leitores. Vale lembrar o apontamento de Cosson (2012, p. 16) em que afirma que: “O corpo linguagem, o corpo palavra, o corpo escrita encontra na literatura seu mais perfeito exercício. A literatura não apenas tem palavras em sua constituição material, como também a escrita é seu veículo predominante". Logo, a literatura, com todo esse conjunto, pode colaborar com a comunicação, desenvolvendo, nas pessoas, a prática de usar diferentes formas para se fazer compreendidas. Essa compreensão, no entanto, vem com a significação daquilo que se lê, o que torna a leitura um prazer

Entende-se que há um despreparo dos docentes ao trabalhar a leitura e leitura literária. Muitos pedagogos/pedagogas acabam sendo considerados despreparados, pois pouco ou quase não trabalham a literatura em sua potencialidade.

A escolha de livros pela escola acaba não sendo eficaz pela falta do diálogo com os saberes dos alunos, o que provoca ainda mais tensão no processo de ensino. Tomemos como exemplo a sacola de leitura: toda semana as crianças levam os livros para casa e devolvem, 
fazendo a troca e entregando uma ficha preenchida, sem escolha, sem nenhum incentivo e, ainda pior, sem um trabalho mediado pelo professor, muitas vezes. Chamamos a atenção que:

Não é possível aceitar que a simples atividade da leitura seja considerada a atividade escolar de leitura literária. Na verdade, apenas ler é a face mais visível da resistência ao processo de letramento literário na escola. Por trás dele encontram-se pressuposições sobre leitura e literatura que, por pertencerem ao senso comum, não são sequer verbalizadas (COSSON, 2012, p. 26).

Cosson (2012) também indaga, com uma simples leitura, como se promove o letramento literário. É necessário que o livro seja de interesse para o aluno também, e não apenas uma escolha da escola ou do professor. É essencial que o livro chame a atenção da criança, sendo pela capa, pelas imagens, ou pelo tema. A leitura deve também partir da escolha do leitor e não do emissor, até mesmo por que:

Um texto não é uma regra clara e objetiva, no qual tudo se encontra e se desvenda. Mas podemos concebê-lo como um emaranhado de palavras carregadas por significantes múltiplos, que se relacionam uns com os outros e assim vão se compondo. Ao leitor cabe decifrá-los e dar-lhes sentidos, porém não se trata apenas de um leitor, verificado pelo senso comum, mas de um sujeito-leitor, isto é, que carrega outros elementos inerentes a ele na imersão dialógica que ele estabelece com o texto, principalmente o elemento social (DERING, 2012, p. 05)

Por essa razão, falamos em um projeto, uma sequência básica para que haja interesse dos leitores, pois, como todo sujeito, ele possui não apenas uma bagagem, mas elementos que vão dialogar com a obra literária. Tendo como base a importância de um linear movimento, Cosson (2012, p. 51) pontua que "A sequência básica do letramento literário na escola, conforme propomos aqui, é constituída de quatro passos: motivação, introdução, leitura e interpretação". A motivação deve aparecer de modo com que o leitor esteja interessado na leitura antes mesmo de ler, como se fosse um prévio conhecimento.

Tem-se como exemplo o andar sempre com livros, pois as crianças costumam se espelhar em um adulto. Pode-se, também, contextualizar a história com o dia a dia do aluno e/ou colocar as crianças em contato com uma biblioteca. Tudo isso é importante, uma vez que é preciso introduzi-las nesse universo da leitura. Cosson (2012) afirma que o aluno deve interagir tanto no princípio estrutural do texto quanto com sua temática. 
Apresentar primeiramente o livro ao leitor é um passo importante; fazer com que a criança vá em busca do livro, tenha mais opções e se desvincule daquilo que seja obrigação é um processo que quebra a ideia de imposição. O contato com a biblioteca, a escolha do livro, entre tantos outros, é uma boa forma de motivação e de introdução para a leitura. Segundo Cosson (2012, p. 60), "Independente da estratégia usada para introduzir a obra, o professor não pode deixar de apresenta-la fisicamente aos alunos”. Assim, não apenas mostrar o livro e estudar a vida do autor, é necessário, além disso, conhecer o contexto, fazer uma pequena e breve leitura para que seja despertado o interesse dos alunos.

A leitura da obra é importante, sem dúvidas, e esta leitura auxilia na interpretação. Cosson (2012, p. 69) aponta que "as possibilidades de registro da interpretação são diversificadas e dependem da turma, dos textos escolhidos e dos objetivos do professor". Para saber se houve a interpretação, então, compartilhar os saberes diversos faz-se necessário, o diálogo entre leitores e mediado pelo professor, sem dúvida, é preponderante.

A pergunta que indagamos é: por que tantas pessoas tem tanta dificuldade de interpretação? Responder a esta pergunta é muito simples, um leitor primeiramente se faz de motivação, em casa ou dentro da escola, mas extremamente essencial na vida de um futuro leitor. Essa motivação, muitas vezes, não se encontra dentro da escola, sendo uma dura realidade, e isso vai depender do professor primordialmente.

Outra questão é a criança que não tem apoio familiar. Mesmo que a escola lhe dê esse acesso livre aos livros, se em casa a criança não recebe a motivação, seja por qualquer razão, dificulta-se a formação desses leitores. A motivação é um elemento essencial para um letramento literário.

Para introduzir um livro em uma sala de aula, o professor pode começar com uma pequena leitura, em que todos possam manifestar-se por meio de vivências ou comentários. É importante que os alunos sintam o livro, que o toquem, que cresça o interesse pela continuação da obra, e que se sintam aguçados à leitura. Assim, para efetivá-la, o professor pode criar intervalos de leituras, que é um combinado entre os alunos, por exemplo, ler determinado capítulo até tal data, deste modo, todos estarão sincronizados, para a interpretação.

A primeira forma de interpretação é realizar a leitura de elementos mais “básicos”, falar sobre o título, sobre o geral da obra, o que mais chamou a atenção (ainda antes da leitura), pode ser em forma de diálogo ou escrito. Vale lembrar que leituras individuais e coletivas serão importantes para que o aluno sinta a liberdade de falar sobre o assunto em momentos distintos. 
Na contextualização, que é denominada a história da obra, Cosson (2012) apresenta sete tipos de contextualização que são: a) Teórica: para verificar os conceitos da obra; b) Histórica: trata do tempo da história, qual época; c) Estilística: são os períodos literários; d) Poética: estudo do funcionamento das obras literárias; e) Crítica: Ler a crítica de determinada obra; f) Presentificadora: união do contexto da obra com o que acontece no presente; g) Temática: estudo literário em forma de debate, onde haverá troca de conclusões da presente leitura.

Depois desses sete passos para um letramento literário, o leitor irá para a segunda interpretação, na qual haverá o aprofundamento da leitura. Cosson (2012, p. 94) aponta que: “o aprofundamento que se busca realizar na segunda interpretação deve resultar em um saber coletivo que une a turma em um mesmo horizonte de leitura".

A expansão na segunda interpretação é quando o professor poderá usar outra obra para fazer uma comparação, essa pode ser escolhida tanto pelo aluno quanto pelo professor. Será que existem limites da sequência expandida? É de interesse do professor saber até onde ele poderá ir. Apesar dessa fala, não é definido um caminho específico até outra sequência, é importante que o professor perceba que há outras possibilidades. Cosson (2012, p. 103) fala que: “Temos certeza, porém, de que o professor interessado no método saberá encontrar nessa orientação geral o seu caminho para um letramento literário adequado aos seus alunos e à sua escola".

Muitos professores escolhem, para seus alunos, livros de seu interesse, pois precisam cumprir com as necessidades da escolarização do literário, apesar de existir imprevistos, é essencial levar em consideração o interesse do estudante. Sobre o limite da sequência expandida, Cosson (2012, p. 106) diz que: “[...] com aplicação ao trabalho de leitura ordenado, mostrando que se há limites no letramento literário, isso se dá mais por força de nossos preconceitos do que pela ausência de capacidade de nossos alunos".

O momento de avaliar é de forma ampla, onde será vista a performance do aluno, do professor e da escola. Cosson (2012), propõe para antes de tudo, que o professor enxergue a literatura como uma experiência, e não como um conteúdo que será avaliado.

Para iniciar a avaliação, constam na proposta da sequência básica, três pontos de apoio, em que o primeiro está na observação de como a leitura está discorrendo, nos momentos de compartilhar os conhecimentos adquiridos, onde nesses momentos de diálogos fazer as correções das leituras, que será um dos momentos dessa avaliação. A segunda e a terceira são os diálogos, onde há compartilhamento e apontamentos da interpretação. Segundo Cosson 
(2012, p. 114), “entendendo-se que essa correção é apenas um momento da avaliação, aquele que aponta um caminho a ser seguido após um diagnóstico do percurso percorrido e a ser percorrido para se atingir determinado objetivo".

O processo de avaliação na sequência expandida também tem três pontos. O primeiro e o segundo funcionam do mesmo modo dos pontos da sequência básica. Já o terceiro ponto será registrado na expansão, em que o relacionamento de ideias precisará de mais cautela e é essencial perceber o interesse do aluno. Escolas conservadoras optam que os alunos façam essa avaliação por meio da escrita; Cosson defende que:

Dentro do processo de letramento literário, consideramos que o investimento em atividades como debates, exposições orais e outras formas de linguagem oral em sala de aula são fundamentais, ou seja, a discussão é uma atividade tão importante quanto aquelas centradas na leitura e na escrita (COSSON, 2012, p. 114-115).

Por fim, a discussão mediada pelo professor, fazendo um papel de moderador, coordenando a discussão para obtenção de melhores resultados. As discussões inicialmente poderão ser feitas em pequenos grupos para depois serem trazidas para o geral, no intuito das falas virem definidas.

\section{Lendo Cora e Conhecendo Nossa História}

Para refletir sobre os pressupostos debatidos de letramento literário, partiremos da obra de Christie Queiroz, um escritor e cartunista goiano, formado em design gráfico pela Universidade Federal de Goiás (UFG), e várias vezes premiado por suas obras, inclusive pela obra Cabeça Oca no mundo de Cora Coralina, lançada em 2007, que recebeu o prêmio de melhor livro infantil pela Abigraf/GO e que será um dos nossos livros de estudo (RIBEIRO, 2018).

\section{Motivação}

Foi escolhida a obra de Christie Queiroz, pelo motivo de ser alvo de grande interesse das crianças, por se tratar de quadrinhos que podem ser encontrados em um jornal bastante popular na cidade de Goiânia e isso já pode ser um ponto para motivação. Pois há um personagem bastante conhecido na região. Cosson (2012, p. 56) fala que: "é preciso lembrar 
que a motivação prepara o leitor para receber o texto, mas não silencia nem o texto, nem o leitor". Outro ponto é por se tratar de uma história que fala da cidade de Goiás, que pode ser do conhecimento do leitor, ou por ser uma cidade próxima, despertar seu interesse em conhecê-la. Quando é apresentada a obra Cabeça Oca no mundo de Cora Coralina, os desenhos da cidade de Goiás podem ser reconhecidos pela maioria dos estudantes, por se tratar de um local conhecido pela maioria, já se podem ouvir frases do tipo: “Eu conheço esse lugar” ou "Eu já vi essa ponte", "Eu já fui lá”, e todos querem contar um pouco do que sabe desse lugar.

\section{Introdução}

A obra Cabeça Oca no mundo de Cora Coralina, enfatiza a escritora Cora Coralina. Quando perguntado sobre ela aos alunos, apesar de ser goiana e nascida na Casa Velha da Ponte, Cidade de Goiás, possivelmente muitos já ouviram falar, mas poucos realmente conhecem. Por essa razão, é interessante apresentar a obra aos alunos, bem como seus pontos de interlocução. Cosson (2012, p. 57), diz que: "Chamamos de introdução a apresentação do autor e da obra". Esta parte é importante pois criamos um vínculo entre obra e leitor.

Para falar do autor do livro, que no caso é Christie Queiroz, não se pode transformá-la em uma longa e expositiva aula, a não ser que seja de interesse dos alunos. O importante é apresentar algo referente apenas à obra que está sendo lida. Segundo Cosson (2012, p. 60), "No momento da introdução é suficiente que se forneçam informações básicas sobre o autor e, se possível, ligadas àquele texto".

Para apresentação da obra, em um processo pedagógico, é papel do professor explicar a importância daquela obra e o motivo pela qual ela foi escolhida. Para a obra Cabeça Oca no mundo de Cora Coralina, seria enfatizado o fato de descobrir juntos as riquezas existentes em Goiás, o que é muito importante, pois faz parte da nossa história, o que também é visto em história do Brasil, na descoberta do ouro, a colonização, entre outros. A parte física da obra também é muito importante, deixar o aluno sentir a capa, fazer a leitura do resumo, mesmo havendo um único exemplar.

\section{Leitura}

No momento da leitura, é essencial o acompanhamento para sanar as dificuldades apenas e não um policiamento. Cosson (2012, p. 62), fala que: “A leitura escolar precisa de acompanhamento porque tem uma direção, um objetivo a cumprir, e esse objetivo não deve ser 
perdido de vista". No caso da obra Cabeça Oca no mundo de Cora Coralina, a leitura seria um tanto extensa para alunos de $4^{\circ}$ ano, suponhamos, nesse caso o professor pode combinar com os alunos de ler, por exemplo, até a página 15, que vai até o momento em que Cabeça Oca, Pião e Empadinha caem em um barranco e começam a rolar campo abaixo. Posteriormente haverá um encontro em que os alunos poderão discutir sobre o que já foi lido. Cosson (2012) chama esses encontros de intervalos, para não acontecer de, em algum intervalo, um aluno que leu além do que foi pedido entregar o suspense. Esse acompanhamento feito pelo professor, e essa definição de até onde ler, é para evitar que alguém entregue o restante da história, estragando para o leitor aquele momento que ele está aguardando desde o começo da obra. Assim, a discussão será igualada, sem estragar o deleite do outro leitor.

Segundo Cosson (2012, p. 64), "É durante as atividades do intervalo que o professor perceberá as dificuldades de leitura dos alunos”. Nos intervalos, é possível perceber no aluno suas dificuldades, poderá também levantar questionamentos para o leitor, como por exemplo, aguçar a curiosidade, como: “Onde será que o Cabeça Oca, Pião e Empadinha vão parar”?, “O que irá acontecer à eles"?, evitando um possível abandono pela leitura da obra. Para Cosson (2012, p. 64), "Em muitos casos, a observação de dificuldades específicas enfrentadas por um aluno no intervalo é o início de uma intervenção eficiente na formação de leitor daquele aluno".

\section{Intepretação}

O momento a interpretação é algo individual e ao mesmo tempo coletivo. Cosson afirma que:

Na escola, entretanto, é preciso compartilhar a interpretação e ampliar os sentidos construídos individualmente. A razão disso é que, por meio do compartilhamento de suas interpretações, os leitores ganham consciência de que são membros de uma coletividade e de que essa coletividade fortalece e amplia seus horizontes de leitura (COSSON, 2012, p. 66).

Para a interpretação da obra estudada, é preciso que os leitores relatem suas conclusões, mas não impede que o professor possa também se expressar no momento de discussão. No momento de atividades de interpretação para alunos de idade entre nove a onze anos, pode-se montar um sketch teatral, em que os leitores poderão incorporar os personagens do livro, 
apresentando pequenos trechos, o que casaria muito bem com a obra e a idade dos alunos. Poderiam recriar uma cena com um dos cômodos da casa de Cora Coralina, evidenciando detalhes citados no livro, apresentariam um trecho da história, poderia ser um momento em que são recitados os poemas de Cora Coralina. Cosson elucida que

para realizar o registro da interpretação, nem sempre é necessário um grande evento como uma feira cultural. O importante é que o aluno tenha a oportunidade de fazer uma reflexão sobre a obra lida e externalizar essa reflexão de forma explícita, permitindo o estabelecimento do diálogo entre os leitores da comunidade escolar (COSSON, 2012, p. 68).

Para a segunda interpretação, pode-se usar a obra da própria Cora Coralina Contas de dividir e trinta e seis bolos (CORALINA, 2011), pois assim será feito um aprofundamento da obra de Christie Queiroz (2015), que versa sobre a vida da escritora Cora Coralina. Com a obra de Cora Coralina que tem um vocábulo pouco usado no nosso dia a dia, poderá ser feito um estudo das palavras usadas na época, além de associar a história do Brasil, período onde ainda existia a escravidão, a palmatória, os métodos de ensino da época, há várias formas e lados para se estender essa obra extraordinária. A obra da Cora Coralina tem grande coerência com a do Christie Queiroz, pois na primeira aparecem fatos históricos, já na do Christie aparece uma cronologia dos fatos acontecidos durante a trajetória de vida de Cora Coralina, o que chama atenção do leitor para fazer a sua própria cronologia de vida. Para Cosson:

\footnotetext{
A adoção do projeto também favorece a diversidade de abordagem da obra e, consequentemente, o desejado aprofundamento da leitura da turma. Do mesmo modo, os interesses dos alunos podem ser contemplados mais facilmente, inclusive com a possibilidade de convivência entre projetos individuais e projetos de grupos. Por fim, desde o planejamento até a apresentação dos resultados, um projeto conduz a vários registros que possibilitam um acompanhamento mais seguro da atividade, assim como facilitam o processo de avaliação (COSSON, 2012, p. 93).
}

$\mathrm{Na}$ avaliação, percebe-se que é possível oferecer vários meios para que ela ocorra. $\mathrm{O}$ objetivo é o aluno alcançar todos os processos para o letramento literário; deve-se avaliar a interpretação que foi feita pelo aluno, que pode não ser a mesma que a sua, onde será discutida, questionada e analisada, para saber se tem concordância com a obra lida. A leitura da obra de Cora Coralina, que fala da palmatória, mesmo não sendo escutada, ou até nunca ter sido escutada por alguns leitores, consegue-se chegar à conclusão que era um meio para se castigar 
crianças que não sabiam as respostas, ou que era um objeto de madeira que servia para aplicar um corretivo ao aluno que não se portava como deveria entre vários motivos. O importante na avaliação é observar onde o aluno conseguiu chegar, e não etapa por etapa.

\section{CONSIDERAÇÕES FINAIS}

O desenvolvimento do presente estudo possibilitou o entendimento da importância da literatura na vida do sujeito. A literatura, como posta na sociedade e nas instituições de ensino, parece ainda não trazer estímulos potenciais na vida dos leitores, pois o modelo atual é ainda retrógrado. Percebeu-se que, em várias instituições, fala-se mais ou prioritariamente, de característica das obras e/ou do autor, deixando de lado o deleite pela leitura, o que acaba afugentando possíveis leitores, trazendo a desmotivação e outros fatores que atrapalham a formação de leitores e a criticidade dos sujeitos.

O estudo da Base Nacional Comum Curricular (BNCC) aponta já possibilidades de afastarmos, em sala de aula, desse modelo supracitado, pois ela mostra as formas para oferecer à prática de leitura, pontuando a importância do contexto do aluno, bem como a utilização de meios tecnológicos, para que, assim, possa ser despertado o interesse dos alunos quanto ao letramento, como por meio de redes sociais ou um clube do livro, entre outros.

É possível compreender que, para tornar o sujeito dono de sua história e ter consciência do que faz, do que diz, dos pensamentos, das atitudes é preciso mostrar o caminho da leitura, que possui a função de tornar a pessoa em um ser autônomo e de opinião própria e não alienado. Além do mais, a literatura nos mostra a transformação da sociedade através da consciência.

Chegando por fim ao letramento literário, que é a grande estrela desse trabalho, é possível compreender que cada etapa de um livro nos traz grandes afirmações, desde a capa até a última página, dialogando com os pontos anteriores, visto que cabe ao sujeito perceber essas potencialidades. Assim, para se tornar leitor literário, não basta apenas ler, deve ter capacidade de exteriorizar o que se leu. Para isso, visualizamos e estudamos cada etapa: a motivação, onde poderá ser mostrada o que aquela obra tem a oferecer; a introdução, momento que é apresentado a obra e o autor; a leitura, instante em que todos podem ter o deleite de descobrir e discutir sobre a obra, levantar pontos importantes; a interpretação, que pode ser individual ou compartilhado. 
Na segunda interpretação, pode-se usar outras obras para aprofundar o assunto e, por fim, tem-se a avaliação, momento em que o importante não é avaliar taxativamente o aluno pelas etapas, mas o que ele alcançou, em um processo contínuo da atividade. Todo o estudo alcançado até aqui nos leva a considerar a extrema importância da leitura literária na vida do sujeito, para sua transformação e para a sociedade em que vive.

\section{REFERÊNCIAS}

ABRAMOVICH, Fanny. Literatura infantil, gostosuras e bobices. São Paulo: Scipone, 1983.

ALVES, Castro. O navio negreiro. In: Os escravos. Belo Horizonte: Editora Itatiaia, 1977

BRASIL. Base Nacional Comum Curricular (BNCC). Educação Infantil e Ensino Fundamental. Versão final. Brasília: MEC, 2017.

CANDIDO, Antonio. Literatura e sociedade. São Paulo: T.A. Queiroz, 2000; Publifolha, 2000.

CORALINA, Cora. Contas de dividir e trinta e seis bolos. São Paulo: Global, 2011.

COSSON, Rildo. Letramento literário: teoria e prática. São Paulo: Contexto, 2012.

DERING, Renato de Oliveira. A cultura de massa em diálogo com questões de teorias

literárias. 104f. Dissertação de Mestrado em Letras. Universidade Federal de Viçosa, Viçosa, Minas Gerais. 2012

DIAS, Gonçalves. Os Timbiras. In: Poesia completa e prosa escolhida. Rio de Janeiro: José Aguilar, 1959.

ECO, Umberto. Sobre literatura. Editora Record. - São Paulo, 2013.

FRANTZ, Maria Helena Zancan. A literatura nas séries iniciais. Petrópolis, RJ: Vozes, 2011.

FREIRE, Paulo, Pedagogia da Autonomia: saberes necessários à prática educativa. Rio de Janeiro: Paz e Terra, 2015.

MARCONI, Marina de Andrade; LAKATOS, Eva Maria. Fundamentos de metodologia científica. São Paulo: Atlas 2003.

PROENÇA FILHO, Dominício. Estilos de época na literatura. São Paulo: Prumo, 2012.

QUEIROZ, CHRISTIE. Cabeça Oca no mundo de Cora Coralina. Goiânia, GO: Ed CMQ, 2015. 
RIBEIRO, Antônio Luiz. Pesquisa Christie Queiroz. In: Guia dos quadrinhos. [Online], 2009. Disponível em: 〈http://www.guiadosquadrinhos.com/artista/christie-queiroz/6910> Acesso em: 07 out. 2018.

TERMI, Fábia. Uma semana na terra de Vera Cruz. São Paulo: Landy, 2000.

VYGOTSKY, Lev. Pensamento e Linguagem. São Paulo: Martins Fontes, 1991. 